\title{
Czy jesteśmy gotowi na wielokulturowość?
}

Streszczenie: Wojna w Syrii spowodowała w 2015 roku masowe migracje uchodźców do Europy, co zostało potraktowane jako narastający problem, a nie wyzwanie. Polska temu wyzwaniu nie sprostała i nie przyjęła żadnych uchodźców. W tym kontekście warto się zastanowić nad tym, czy Polska w ogóle jest gotowa do funkcjonowania we współczesnym zróżnicowanym świecie. Co można zrobić, by tę gotowość podnieść? Kryzys syryjski zakwestionował także dojrzałość Unii Europejskiej jako wspólnoty społecznej i obnażył fakt, że przyświecająca idei stworzenia Unii motywacja oparta na wspólnocie interesów, jest za słaba dla tworzenia kulturowej jedności ${ }^{1}$. W dobie kryzysy syryjskiego, okazuje się, że tożsamość europejska jest nadal krucha.

Słowa kluczowe: emigracja, Syria, wielokulturowość, otwartość, gotowość

Wielokulturowość jako fakt społeczny obejmujący zróżnicowanie wynikające $\mathrm{z}$ akceptowanych aksjologicznych porządków, jest już faktem codzienności cywilizacji Zachodniej. Promowanie wielokulturowości jako wartości, przez lata było przedmiotem zainteresowania humanistów i przedstawicieli nauk społecznych. O ile jednak przez długi czas postulowaliśmy, żeby patrzeć na zróżnicowanie kulturowe jako na wartość, o tyle dzisiaj okazuje się, że praktyka społeczna jest od tych postulatów bardzo odległa. To, co na gruncie rozważań teoretycznych zostało już przyjęte jako pewnik, na gruncie empirii życia codziennego napotyka na brak zrozumienia. Niestety, także w mediach masowych widoczne są tendencje podkreślania wątków sensacyjnych, niekorzystnie prezentujących zróżnicowanie kulturowe - w tym sensie często media masowe kierują się zyskownością a nie sensownością informacji - media są też narzędziami świadomie wykorzystywanymi przez siły terrorystyczne w propagowaniu swojej ideologii. Anthony Giddens pisze w tym kontekście:

1 Por. także: „Rola, jaką Unia odgrywała od swoich wczesnych dni, w dalszym ciągu jest bardzo ważna, chociaż podlega zdefiniowaniu na nowo. Oznacza to, że UE istnieje po to, aby przynieść swoim członkom korzyści gospodarcze, których inaczej by nie miały" (Giddens, 2009, s. 244). 
"Nowy terroryzm jest geopolityczny, jest wytworem globalizacji i komunikacji masowej" (Giddens, 2009, s. 244), wskazując, że ruchy terrorystyczne także dysponują swoimi mediami, traktowanymi jako narzędzia promowania jednostronnych idei - w zasadzie także wspierających niechęć do zróżnicowania kulturowego. Dlatego właśnie warto pogłębić refleksję nad tym, czy cywilizacja zachodnia, jest de facto gotowa na wielokulturowość. Okazało się bowiem, że w świetle aktualnej sytuacji w Europie, jest dokładnie przeciwnie, niż byśmy mogli oczekiwać. I to pomimo długotrwałego i intensywnego promowania zróżnicowania kulturowego jako wartości. Niezaprzeczalnie na nasilanie negatywnego stosunku do wielokulturowości wpływ mają ataki terrorystyczne, które są coraz liczniejsze, i które budzą niepokój oraz narastające poczucie zagrożenia. Prowadzone statystyki dotyczące liczby takich ataków są zatrważające: wskazuje się, że w samym tylko roku 2017 zrealizowano 934 ataki, w których zabito 5466 osób (https://storymaps.esri.com/stories/ terrorist-attacks/?year=2017). Treści o aktach terrorystycznych, w zrozumiały poniekąd sposób dominują emocjonalnie przekazy formułowane dla opinii publicznej, co odzwierciedlane jest w niechęci licznych społeczności do przyjmowania ludności napływającej zza granic kraju. Jest to sytuacja tym trudniejsza, że szczególnie te kraje europejskie, które mają za sobą kolonialną historię, zbierają teraz niechciane żniwo narzucania w koloniach własnej kultury i języka. Migranci z obszarów byłych kolonii, w sposób automatyczny wybierają na kraje docelowej emigracji te państwa, które występowały jeszcze sto lat temu w roli „protektorów”.

Szczególna sytuacja masowych migracji została w zasadzie wywołana przez nasilające się konflikty zbroje w Syrii, które spowodowały fale emigracje ludności do Europy. Początki tej fali migracji należy lokować w roku 2015, jednak w 2016, a szczególnie w roku 2017, sytuacja przyjęła bardzo krytyczną postać. Wysoka Komisja Narodów Zjednoczonych do Spraw Uchodźców podaje dane na koniec sierpnia 2017, wedle których do krajów europejskich leżących nad Morzem Śródziemnym, od początku roku 2017 przybyło drogą morską 123950 osób. Liczbę osób zaginionych i zmarłych szacuje się na 2421 osób. Dane statystyczne za poprzednie lata wskazują następujące liczby osób:

Tabela 1. Opracowanie własne na podstawie http://data2.unhcr.org/en/situations/ mediterranean

\begin{tabular}{|l|c|r|r|r|}
\hline & 2014 & \multicolumn{1}{|c|}{2015} & 2016 & 2017 do 31.08. \\
\hline Przybywający drogą morska & 216,054 & $1,015,078$ & 362,753 & 123,950 \\
\hline Zmarli i zaginieni & 3,538 & 3,771 & 5,096 & 2,421 \\
\hline
\end{tabular}


Jak wskazują powyższe statystyki, kryzys syryjski spowodował rzeczywiście masowy napływ ludzi z obszarów zagrożonych działaniami wojennymi do Europy, co z kolei wymusiło na państwach europejskich podjęcie usystematyzowanych kroków regulowanych instytucjonalnie: w ten sposób sformułowane zostały postulaty do krajów członkowskich Unii Europejskiej, o przyjmowanie uchodźców. Z punktu widzenia solidarności ludzi oraz promowania wartości humanistycznych, jest to jedyny możliwy kierunek do zaproponowania. Zaznaczyć należy jednak, że Unia Europejska nie była chętna do podjęcia tego kroku - było to podstawą krytykowania Unii Europejskiej przez organizacje charytatywne w roku 2015. Kanclerz Angela Merkel w przemówieniu w Bundestagu w 2015 roku opowiedziała się za wprowadzeniem kontyngentów uchodźców, którzy co roku byliby przyjmowani przez Unię Europejską. Wskazała jednocześnie, że przyszłość strefy Schengen zależy od tego, czy cała Europa weźmie udział w kwotowym systemie rozdziału migrantów. To, co było też bardzo istotne w jej wystąpieniach, to podkreślanie solidarności i jedności Unii Europejskiej oraz konieczność rozwiązania problemu migracji na poziomie likwidowania ich przyczyn. W roku 2017 wobec Polski i Węgier, jako krajów najsilniej opierających się przyjmowaniu emigrantów, Komisja Europejska rozpoczęła procedury karne za złamanie postanowień Unii Europejskiej z roku 2015 dotyczących przyjmowania poszukujących azylu.

Polska uchyla się od tego zobowiązania, mimo że jest ono wspólnym zobowiązaniem wszystkich krajów członkowskich UE. Prócz tego, że takie zaniechanie realizacji postanowień wskazuje na nielojalną postawę wobec innych krajów unijnych, przyjmowanie emigrantów jest moralnym obowiązkiem, każdego państwa, w którym panuje pokój. O ile bowiem różnie można oceniać motywacje ludzi migrujących na całym świecie, o tyle emigracje spowodowane działaniami wojennymi w kraju pochodzenia są szczególnie dramatyczne. Postawę Polski należy skomentować krytycznie. Nie ma od tego odwołania. Szczególnie poruszające są medialne doniesienia na temat sytuacji osób cywilnych, w tym dzieci, które znalazły się pośród tych działań wojennych. Nieudzielanie pomocy tym osobom jest wysoce niemoralne. Szczególnie dla kraju, którego rząd definiuje się jako nawiązujący do wartości chrześcijańskich i opierający swoją publiczną retorykę o zasady poszanowania bliźniego i troski o niego.

Polska ma długie i silne tradycje migracyjne i w tym kontekście opór wobec przyjmowania migrantów jest szczególnie zaskakujący. Wydawać by się bowiem mogło, że powinniśmy jako naród mieć w pamięci te wszystkie fale 
migracji, które pozwalały Polakom ocaleć, przeżyć, zdobyć źródła utrzymania. W najnowszej naszej historii dotyczy to choćby migracji „za chlebem” w okresie międzywojennym; migracji spowodowanych działaniami wojennymi w latach 1939-1945, a także trudnych do zrealizowania migracji politycznych okresu powojennego, kiedy Polacy w poszukiwaniu wolności słowa i życia, ale także w poszukiwaniu lepszych warunków codziennej egzystencji, robili wszystko by wyemigrować „na Zachód”. Ucieczka przed opresją rządów totalitarnych narzucanych przez Związek Radziecki jest pamiętna. Po wejściu Polski do Unii Europejskiej rozpoczęły się migracje motywowane jeszcze inaczej: dążeniami do samorealizacji, kształcenia, poszukiwania swoich korzeni i tożsamości, a także po prostu wygodniejszego życia. Wspomnieć oczywiście także należy falę migracji z Polski do USA w wieku XIX i na przełomie XIX i XX.

Raport GUS z 2015 roku donosi: „Migracje zagraniczne są zjawiskiem społeczno-ekonomicznym na trwałe wpisanym we współczesną historię Polski. Po zauważalnym spadku liczby Polaków przebywających czasowo za granicą w latach 2008-2010, rok 2015 był kolejnym rokiem zwiększenia się zasobu imigracyjnego Polaków w innych krajach - przy czym wzrost ten był mniejszy niż w roku poprzednim. W wyborze kraju emigracji odgrywają znaczną rolę nie tylko warunki życia w kraju przyjmującym i stosunek do imigrantów mieszkańców tego kraju, ale również uwarunkowania historyczne, bliskość kraju oraz w ogromnej mierze ukształtowane sieci migracyjne - informacje o doświadczeniach krewnych, sąsiadów i znajomych" (GUS, 2015, s. 1) oraz dalej następuje uszczegółowienie tych danych: „Szacuje się, że w końcu 2015 roku poza granicami Polski przebywało czasowo około 2397 tys. mieszkańców naszego kraju, tj. o 77 tys. (3,3\%) więcej niż w 2014 roku. W Europie w 2015 roku przebywało około 2098 tys. osób, przy czym zdecydowana większość - około 1983 tys. - przebywała w krajach członkowskich UE. Liczba ta zwiększyła się o 82 tys. w stosunku do 2014 roku. Spośród krajów UE, nadal najwięcej osób przebywało w Wielkiej Brytanii (720 tys.), Niemczech (655 tys.), Holandii (112 tys.) oraz w Irlandii (111 tys.) i we Włoszech (94 tys.)" (http://stat.gov.pl/obszary-tematyczne/ludnosc/ migracje-zagraniczne-ludnosci/informacja-o-rozmiarach-i-kierunkach-emigracji-z-polski-w-latach-20042015,2,9.html). Raport GUS wskazuje więc, że nawet w okresie pokoju, migracje Polaków za granicę rosną. Jest to tendencja charakteryzująca w tej chwili niemal cały świat, a na pewno kraje wysokorozwinięte: mobilność jest jedną z podstaw funkcjonowania społeczeństw ponowoczesnych (por. Bauman, 2004). 
Jakkolwiek decyzje Polski wobec Unii Europejskiej dotyczące odmowy przyjęcia emigrantów, są decyzjami rządowymi, tak niestety społeczna niechęć wobec przyjmowania migrantów także rośnie. Raport z badań zrealizowanych przez CBOS w kwietniu 2017 roku, wskazuje: „Od maja 2015 roku, gdy zaczęliśmy badać tę kwestię, Polacy niezmiennie są w większości sceptycznie nastawieni do relokacji uchodźców przybyłych do Unii Europejskiej z Bliskiego Wschodu i Afryki. Co więcej, od grudnia 2015 roku odsetek zdecydowanych przeciwników przyjęcia części uchodźców przybywających do Europy jest wyższy, niż łączny odsetek umiarkowanych i zdecydowanych zwolenników. Podobnie jest także w tym miesiącu. Obecnie relokacji sprzeciwia się trzy czwarte (74\%) badanych, co jest najwyższą wartością spośród dotąd notowanych, przy czym dominującą odpowiedzią jest zdecydowany sprzeciw (43\%). Za przyjęciem uchodźców opowiada się w sumie nieco więcej niż jedna piąta Polaków (22\%) - to spadek o 6 punktów procentowych w stosunku do grudnia 2016 roku - gdy po raz ostatni zadaliśmy to pytanie." (CBOS, 2017, s. 3). Ważną zmienną modyfikująca opinie w tym zakresie są preferencje polityczne - „stosunek do relokacji uchodźców w obrębie Unii Europejskiej jest w wyraźny sposób związany z deklarowanym stanowiskiem politycznym, ale nawet wśród wyborców lewicy - najlepiej nastawionych do tego rozwiązania - poziom akceptacji wynosi jedynie 37\%. Zdecydowanie najmniej przychylni są zwolennicy prawicy: więcej niż czterech na pięciu spośród nich (82\%) sprzeciwia się przyjęciu części uchodźców" (CBOS, 2017, s. 4).

Należy przytoczyć jeszcze jeden cytat ze wspomnianego raportu: „utrzymuje się także obserwowane wcześniej zróżnicowanie opinii w grupach społeczno-demograficznych. Relatywnie najczęściej za przyjmowaniem uchodźców opowiadają się mieszkańcy największych miast (39\%), posiadający wyższe wykształcenie (33\%), badani o najwyższych dochodach per capita (29\%). Przeciwnikami relokacji najczęściej są respondenci najmłodsi (87\% przeciwników wśród osób w wieku 18-24 lata) i osoby uczestniczące w praktykach religijnych co tydzień (77\%) lub częściej (86\%)" (CBOS, 2017, s. 5). Ten fragment wskazuje na szczególną niechęć do przyjmowania uchodźców ze strony osób, których sytuacja materialna jest zła. A więc tych osób, które potencjalnie także mogłyby w najbardziej prawdopodobnym stopniu, szukać lepszego miejsca do życia poza granicami Polski. Dotyczy to uchodźców niezależnie od tego, z jakiego kraju pochodzą. Odzwierciedla to psychologiczne, już zbadane mechanizmy funkcjonowania ludzi, prowadzące do narastania antypatii i konfliktów na tle zróżnicowania etnicznego, w sytuacji niedoboru 
zasobów (por. Aronson, 2005, s. 278-335). Psychologiczny mechanizm powstawania takiej postawy jest zrozumiały. Jego wzmacnianie poprzez działania propagandowe o podłożu ideologicznym - nie. Nie wspominając, że tego rodzaju działanie nie jest etyczne, a moralnie naganne.

Generalnie więc wyniki sondaży empirycznych wskazują, że poziom akceptacji przyjęcia do Polski uchodźców spada i jest nieco niższy niż w grudniu 2016 roku. Jedynie około 20\% Polaków zgodziłoby się na relokację uchodźców z państw Bliskiego Wschodu i Afryki przybywających do Unii Europejskiej. Polacy są znacznie lepiej nastawieni do możliwości przyjęcia uciekinierów ze wschodniej Ukrainy - akceptuje to ponad połowa badanych (55\%). Bardziej przychylne przyjmowaniu uchodźców są osoby lepiej wykształcone, zamożniejsze, mieszkające w największych miastach, a także starsze. Warto się zastanowić nad mechanizmem działania, który leży u podłoża tego oporu wobec udzielania wsparcia uchodźcom. Jak widzę specyfikę tej sytuacji:

1. W pierwszym rzędzie należy uznać z dużym prawdopodobieństwem, że niechęć wobec uchodźców jest fenomenem wykreowanym poprzez wykorzystanie mediów masowych i ich wpływ na ocenę sytuacji dokonywaną przez obywateli Polski. Taki wniosek wysunąć należy na tej oto podstawie, że nigdy nie wyznaczono konkretnej liczby osób, jaka miałaby być do Polski potencjalnie przyjęta. Nie mając tej informacji, w zasadzie nie można rzeczowo ocenić wpływu migrantów na różne aspekty społeczno-kulturowej rzeczywistości Polski. Lęk przed przyjmowaniem uchodźców nie jest więc oparty na racjonalnych kalkulacjach zasobów, ale na irracjonalnym przekonaniu o charakterze uprzedzenia. To niechętne wobec uchodźców nastawienie Polaków odzwierciedla postawy roszczeniowe. W istocie rzeczy bowiem udzielenie azylu nawet 100 osobom, w skali państwa, jakim jest Polska, nie stanowi ani znaczącego uszczerbku finansowego, ani nie pozwala na istotny wpływ kulturowy. Ewentualne przyjęcie uchodźców miałoby sens jedynie symboliczny, podkreślający przynależność do wspólnoty, zainteresowanie nią i chęć uczestniczenia w rozwiązywaniu jej problemów. Postawa roszczeniowa i zawłaszczająca - może być także zrozumiała w świetle niedoboru zasobów, nie jest zrozumiała w tak prosty sposób w sytuacji dostępności zasobów. Postawa roszczeniowa tego rodzaju ujawnia się także w formie innego zjawiska - żądania (od potencjalnych beneficjentów pomocy) okazywania wdzięczności za oferowaną pomoc i wdrażania się w wyznaczony przez darczyńcę tryb postępowania. Te oczekiwa- 
nia widoczne są $\mathrm{w}$ formułowaniu wobec potencjalnych emigrantów zarzutów o to, że są niewdzięczni, oraz że nie chcą „na stałe” zostawać w Polsce, że traktują Polskę jako kraj tranzytowy w migracyjnej drodze na Zachód Europy. Trudno się temu dziwić - to racjonalne rozwiązania. Nie tylko dlatego, że poziom dobrostanu jest tam wyższy, państwa te oferują znaczniejsze wsparcie socjalne, ale także dlatego, że istnieje tam już kulturowa baza uchodźców z tych samych krajów, stanowiąca logistyczne i emocjonalne wsparcie dla nowoprzybyłych.

2. Po drugie - warto przeanalizować obawy dotyczące wpływu przybycia migrantów na własną sytuację ekonomiczną. Polska nie jest państwem oferującym znaczące wsparcie socjalne - nie oferuje go ani swoim obywatelom, ani przybyszom. Obawa przed pogorszeniem się własnej sytuacji ekonomicznej nie wydaje się być uzasadniona. Szczególnie, jeśli wziąć pod uwagę, że liczbę migrantów można ograniczyć, a tym samym zmniejszyć zakres poniesionych kosztów. Podkreślając niski poziom świadczeń socjalnych w Polsce, obawy znów wydają się iluzoryczne.

3. Po trzecie - mamy do czynienia z pewnego rodzaju lękami, wzmacnianymi przez media masowe o rysie prawicowym, zgubnego wpływu kultury przybyszy, na kulturę polską. Potencjalne te wpływy należy oceniać jako znikome, szczególnie w przypadku ograniczenia liczby przyjmowanych osób. Werbalizowanie obaw przed zagrażającym wpływem innych kultur na rodzime wartości, jest dowodem skrajnego nieprzystosowania do funkcjonowania w zglobalizowanym świecie, gdzie przepływy treści kulturowych są nieuniknione. Nastawienie izolacjonistyczne bywa nadal stosowane jako strategia zachowania swojej tożsamości (na przykład przez amiszów, ortodoksyjnych Żydów, Romów) - ale jest to strategia marginalna i realizowana wybiórczo, niekonsekwentnie.

4. Podsumowując - w świetle powyższego, jako przyczyna niechęci do emigrantów, rysuje się postawa Polaków, którą można określić jako roszczeniową, opartą na nieuzasadnionych lękach i obawach, wskazująca na brak przystosowania do funkcjonowania w nowoczesnych (czy ponowoczesnych) typach wspólnot.

Kwestię relokacji uchodźców w obrębie Unii Europejskiej należy więc traktować jako pytanie dotyczące funkcjonowania Wspólnoty. Nie tylko wspólnoty rozumianej jako Unia Europejska, ale przede wszystkim w szerszym wymiarze - mianowicie wspólnoty traktowanej jako wspierająca się grupa ludzi, wyznająca podobne wartości humanistyczne. Oczywiście definiowanie „podobnych wartości” jest niezwykle trudne: bo to co jest czytelne 
na poziomie formułowania norm (np. podnoszenie jakości życia ludzkiego), na poziomie tworzenia dyrektyw może przyjmować skrajnie rozbieżne interpretacje (np.: poprzez industrializację lub wręcz przeciwnie - poprzez nasilanie kontaktu z naturalnym środowiskiem przyrodniczym). Kryzys europejski, jaki notujemy w obliczu fali migracji powstałej na bazie wojny w Syrii, wskazuje, że wspólnota europejska jest słaba - trudne bowiem jest kreowanie nowych procesów regulujących tę nową rzeczywistość (objawia się to w omawianym przypadku trudnościami i sporami odnośnie przedmiotowej kwestii). Polska nie zdała tego egzaminu w ogóle. Odmowa przyjęcia uchodźców wskazuje nie tylko na skrajnie niehumanitarne podejście do innych ludzi, ale też na nielojalność wobec wspólnoty. Efektywny udział w działaniach wspólnoty zakłada bowiem wyznaczenie pewnych zakresów rezygnacji z własnego komfortu, na rzecz komfortu innych, po ty by w innych zakresach, reguła mogła zadziałać odwrotnie. W odniesieniu do Unii Europejskiej mamy do czynienia z taką jej specyfiką, gdzie jej podłoże nie jest oparte na wspólnocie wartości kulturowych, ale na wspólnocie interesów. To powoduje, że odmiennie niż w Stanach Zjednoczonych Ameryki, poziom zorientowania na wspólnotę jest znacznie niższy. Działania o charakterze wspierającym na rzecz sprawności wspólnoty stanowią w USA ważny element kultury. Kryzys emigracyjny wskazuje, że w Europie tego rodzaju wartości nadal są słabe i to nie one jednoczą obywateli. W wymiarze psychologicznym - sytuacje kryzysowe, definiuje się jako takie, które wymuszają kreowanie nowych sposobów zachowania, bowiem te dotychczasowe nie są już funkcjonalne. Ta definicja obejmuje tak kryzysy o wydźwięku negatywnym, jak i pozytywnym. Umiejętność radzenia sobie z kryzysem polega na racjonalnym podejściu zadaniowym do sytuacji i wypracowaniu racjonalnych strategii. Zastosowana przez Polski rząd strategia unikania poprzez odrzucenie projektu przyjęcia uchodźców, nie jest psychologicznie dojrzałym rozwiązaniem. Najbardziej pozytywnie do projektu przyjmowania emigrantów nastawieni są ludzie opowiadający się za wspólnym ustalaniem polityki migracyjnej i azylowej, a także za dążeniem do pełniejszej integracji społeczności.

Znów w wymiarze psychologicznym - podkreślić należy, że taka postawa odrzucająca odmienność świadczy jednoznacznie o nieugruntowanej tożsamości, „obawiającej” się kontestacji. Teoria tożsamościowa określa, że w rozwoju człowieka w bliżej niezawężonym, okresie dzieciństwa (mniej więcej około 5 roku życia) rozpoczyna się ten etap definiowania siebie, gdzie najbardziej istotna dla budowania Ja jest akceptacja rówieśników. Wszelkie odmienności są wtedy bezpardonowo odrzucane na społeczny margines, jako takie 
które właśnie tej tworzącej się tożsamości zagrażają. Po uzyskaniu poczucia bycia akceptowanym, w okresie adolescencji następuje przejście do etapu indywidualizowania, kiedy to właśnie odmienność jest traktowana jako wartość. Może tak się dziać ponieważ jednostka, uzyskała poczucie akceptacji, pewności i wysokiej samooceny od swojej grupy rówieśniczej we wcześniejszym stadium rozwojowym. Ten psychologiczny proces znajduje analogię na poziomie prawidłowości społecznego rozwoju grupy. W grupach o nieukształtowanej tożsamości istnieją znaczące pokłady leku, nasilające agresję, negację lub odrzucenie w stosunku do innych, w szczególności znacznie się różniących od grupy, ludzi. W zasadzie mówimy tutaj o specyfice rozwoju tożsamości kulturowej polskiego społeczeństwa (por. Mamzer, 2002), która jednak jest na tyle niedojrzała, że nawet po wezwaniach papieża Franciszka i Arcybiskupa Gondeckiego do przyjmowania uchodźców - choć pojawiła się we wszystkich w zasadzie mediach burzliwa dyskusja na ten temat, sytuacja nie uległa zmianie i Polska uchodźców nie przyjęła. Prowadzi nas to do smutnej konstatacji, która jest odpowiedzią na tytułowe pytanie - na metapoziomie refleksji stwierdzić należy, że na obcowanie z wielokulturowością nie jesteśmy gotowi. Mamy także problem $\mathrm{z}$ budowaniem i utrzymaniem wspólnotowości, która byłaby na tyle trwała żeby jednoczyła obywateli i dawała im poczucie nie tylko wsparcia i bezpieczeństwa, ale także odpowiedzialności za innych.

Tak jak niechęć do przyjmowania uchodźców w Europie a w Polsce w szczególności, traktować należy w kategoriach kryzysu wspólnoty w wymiarze szerszym, niż tylko unijny, tak równie szeroko należy potraktować brak gotowości na wielokulturowość. Ten szeroki wymiar w tym przypadku, odnosi się do zróżnicowania społecznego w wielu aspektach. Ostatnie dwa lata polskiej rzeczywistości pokazują, że nie wypracowaliśmy dotąd jako społeczeństwo otwartości na zróżnicowanie w ogóle. Wielokulturowość stanowi jedynie jedną z możliwych egzemplifikacji zróżnicowania społecznego - szczególnie jeśli definiować kulturę za Jerzym Kmitą, jako rzeczywistość myślową, podzielaną przez daną społeczność i opartą na respektowanych powszechnie regułach normatywnych i dyrektywalnych (por. Banaszak i Kmita, 1991). W takim rozumieniu kultura ma podłoże aksjologiczno-normatywne, a nie etniczne. Wielokulturowość należy więc traktować w tym sensie jako metaforę zróżnicowania społecznego.

Anthony Giddens pisze: „w przeszłości tożsamość narodowa powstawała i była podtrzymywana w opozycji do innych - wrogich państw lub koalicji takich państw. Podziały zimnej wojny były ostatnią wersją takiej dynami- 
ki. Wiele państw, w tym państwa UE, musi obecnie zdefiniować swoją tożsamość w inny sposób. (...) Relacje geopolityczne są w dużej mierze takie jak zdefiniują je przywódcy ważnych państw" (2009, s. 244). Nie mamy dotąd wypracowanej strategii budowania wspólnot, bez antagonizowania ich a przynajmniej przeciwstawiania innym wspólnotom. Jest to coraz bardziej dramatyczne zadanie do wykonania. W cytowanej pracy Giddens definiował wspólne wartości europejskie: „UE reprezentuje wartości ogólne, które uosabia i których broni. Uważam za nie: kultywowanie i ochronę demokracji wewnątrz i na zewnątrz Unii; tworzenie jednorodności z różnorodności - sformułowanie to nie jest jedynie sloganem odnoszącym się do kosmopolitycznej natury UE - promowanie solidarności wewnątrz unii w różnych znaczeniach tego słowa (...) zdolność do współpracy w obliczu zagrożeń zewnętrznych i zdolność do konstruktywnego zaangażowania w problemy i konflikty szerszego świata" (Giddens, 2009, s. 248). Praca ta ma już dziesięć lat (w języku angielskim została opublikowana po raz pierwszy w roku 2007), jej postulaty pozostają niezmienione, jednak do postrzegania Unii dołożyły się w tej chwili sytuacje, które jednoznacznie pozwalają odpowiedzieć na tytułowe pytanie teksu - do wielokulturowości jeszcze nie dojrzeliśmy.

\section{Bibliografia}

Aronson, E. 2005. Człowiek istota społeczna. Warszawa: PWN.

Banaszak, G., i Kmita, J. 1991. Społeczno-regulacyjna koncepcja kultury. Warszawa: Instytut Kultury.

Bauman, Z. 2004. Życie na przemiał. Kraków: Wydawnictwo Literackie.

Giddens, A. 2009. Europa w epoce globalnej. Warszawa: PWN.

Mamzer, H. 2002. Tożsamość w podróży. Poznań: UAM.

CBOS. Kwiecień 2017. Komunikat z badań „Stosunek do przyjmowania uchodźców" nr 44.

http://data2.unhcr.org/en/situations/mediterranean (data dostępu: 1.09.2017).

http://stat.gov.pl/obszary-tematyczne/ludnosc/migracje-zagraniczne-ludnosci/informacja-o-rozmiarach-i-kierunkach-emigracji-z-polski-w-latach-20042015,2,9.html (data dostępu 1.09.2017).

https://storymaps.esri.com/stories/terrorist-attacks/?year=2017 (data dostępu 6.09.2017). 


\section{Are we ready for multiculturalism?}

Abstract: The War In Syria has caused massive migration movements to Europe In 2015. European Union Has defined the situation as the threat not as a challenge. Neither European Union, neither Poland have manager to Deal with this challenge. In such a context one needs to post the question: is oland ready for multiculturalism and is it ready to function well in globalized, diverse world of $21^{\text {st }}$ century. The crisis in Syria has also questioned maturity of EU as social community. It appears, that facing Syrian crisis, Europe and Poland especially demonstrated lack of understanding, consciousness and sense of community, with those searching for asylums.

Keywords: Emigration, Syria, multiculturalism, openness, readiness

Translated by Hanna Mamzer 